\title{
Customer Service Failure Evaluations in Diverse Airlines Business Models
}

\author{
Havayolu Iş Modellerinde Müşterilerin Hizmet Hatası Değerlendirmeleri
}

\author{
Birce DOBRUCALI' \\ Bengü OFLAÇ²
}

\begin{abstract}
Even though it is impossible to eliminate all failures in a service encounter, due to their negative outcomes, airlines' strive at minimizing failures as much as possible. Customers may act differently after failures, but the important point for airlines is to understand the underlying psychological mechanisms for prevention. In this regard, this study reveals the dynamics by which expectancies of passengers affect stability attribution, word of mouth (WOM) and repurchase intentions after exposing service failures in diverse airlines business models. Structural equation modeling is used to compare models in two airlines business contexts: low cost carriers (LCCS) and flagship airlines. Findings demonstrate that for LCC, passengers' expectations positively affect stability attributions. Additionally, stability attribution following flagship airlines service failure is found to have a negative effect on repurchase intentions. Finally, findings indicate that following both LCC and flagship service failures, stability attribution decreases WOM intention of passengers.
\end{abstract}

Keywords: Low cost carriers (LCC), Flagship airlines, Service failure, Attribution theory, Structural Equation Modeling (SEM)

JEL Classification: M31, L39

\section{Introduction}

Airlines service providers strive at minimizing failures as much as possible due to its critical results

\section{ÖZET}

Hizmet sunumu sürecindeki tüm hataların ortadan kaldırılması imkânsız olsa da, havayolları, hizmet hatalarını, doğurdukları olumsuz sonuçlarından dolayı en aza indirgemeye çalışmaktadır. Müşteriler yaşadıkları hizmet hatalarına farklı tepkiler verseler de, havayolları için önemli olan nokta, müşterilerin verdiği bu tepkilerin altında yatan psikolojik mekanizmaları anlamaktır. Bu bağlamda, bu çalışma, farklı iş modellerinde hizmet veren havayolu şirketlerinin hizmet hatalarını takiben yolcuların beklentileri ile değişmezlik atfı, ağızdan ağıza pazarlama ve yeniden satın alma niyetleri arasındaki dinamikleri ortaya koymaktadır. Yapısal eşitlik modellemesi, iki havayolu iş modelini karşılaştırmak için kullanılmaktadır: düşük maliyetli taşıyıcılar (LCC'ler) ve bayrak taşıyıcı havayolları. Bulgular, düşük maliyetli havayolları için, yolcuların beklentilerinin değişmezlik atıflarını olumlu etkilediğini göstermektedir. Buna ek olarak, bayrak taşıyıc havayollarının hizmet hatasını takip eden değişmezlik atfının, yeniden satın alma niyetleri üzerinde olumsuz bir etkisi olduğu bulunmuştur. Son olarak, bulgular hem düşük maliyetli hem de bayrak taşıyıcı havayollarının hizmet hatalarını takiben, değişmezlik atfının ağızdan ağıza pazarlama niyetini azalttığını göstermektedir.

${ }^{1}$ Research Assistant, Izmir University of Economics, Faculty of Business, Department of International Trade and Finance, 
cannot be eliminated, for taking either corrective or preventive actions, it is crucial for service providers to understand passengers and the altering causes that shape behavioral intentions. While digging into that issue, airlines should also be aware of the fact that customers using a particular type of service provider evaluate an event related to that type of service provider (Smith and Bolton, 1998).

With the global spread of deregulation and globalization of aviation market, the civil aviation market became more commercialized and number of airline service providers has started to increase resulting in the improvement of business models of low-cost carriers (LCC) and full network service airlines (FNSA) (Ozenen, 2003; Vidovic et. al., 2013). Core characteristics of FNSA include complex pricing structure, usage of primary airports, various class of seating (economic, business and first class), intensive usage of aircraft, free food and beverage delivery during flight, longer turnaround times and reliable customer service (O'Connell, 2005; Williams, 2001). In most cases, the flagship airlines, in other words national carriers (e.g. Turkish Airlines, British Airlines, Air France/KLM, and Austrian Airlines) carry the characteristics of FSNAs (Vidovic et al., 2013). Flagship airlines are defined as; airlines registered in a state, have privileges, are or were owned by the government, and hold their privileges even long after its privatization (Sull, 1999).

Low cost carriers (LCCs), budget or discount airlines, focus on cost leadership strategy and offer low-priced flight option to passengers by delivering no frills service, reducing expenses and using secondary airports with cheaper landing charges (Hunter, 2006). Main characteristics of LCCs can be listed as; shorter turnaround times, bundling food and beverage delivery during flight, single seating class option, high aircraft utilization, one-type aircraft fleets, minimum cabin crew with lower wage scales, point to point service and no connections (Mason, 2000; Doganis, 2001; Williams, 2001; Francis et al, 2004; O'Connell, 2005; Taumoepeau et al., 2017). Ryanair, EasyJet, and Pegasus Airlines, Debonair can be counted as successful examples of LCC.

Flying with a specific kind of airlines can alter and reshape behavioral intentions. More specifically, there is a possibility for passengers to act differently with the impact of their airlines' format based preset expectations. Parallel to these arguments, we aim to shed light on following questions: Do expectations impact stability attributions after airlines service failures?
Does this relationship changes according to the type of airlines? Do stability attributions affect behavioral intentions (WOM and repurchase intentions) and do those relations change based on the airlines business models?

Even though airline service failures are widely studied in the literature, there exists a lack of understanding the role of expectations on their attribution behavior and post-failure intentions in relation with the airlines business models. By developing and examining the proposed research model (Figure 1) for both low cost and flagship airlines, this research is expected to provide more precise managerial implications for airlines industry.



\section{Figure 1. Research Model}

\section{Theoretical Framework}

\section{Expectancy Theories in Service Failures}

Hess et al. (2003) explained service failure as the case where the provided service lacks the capability of meeting the expectation of customers. In airlines context, various situations ranging from flight cancellation due to weather conditions to check-in officer's misbehavior towards passenger may be interpreted as a service failure. With regard to the aforementioned definition, service failure perception and expectations are interrelated notions. Expectation is a belief or an estimation regarding the input's result in a certain level of performance (Teas, 1981) and also be defined as individualistic standards against which quality of received service is judged (McDougall and Levesque, 1998). Customers' expectations of a service is either determined before the first transaction with the company (through WOM or advertisements), by personal experience (Davis and Heineke, 1998) or service provider's image (Grönroos, 1984), and promises (Boulding et al., 1993). In airlines context, expectations have been taken into consideration in relation with LCC and FSNA business models. Wittman (2014) stated that LCC passengers hold lower expectations regarding quality of received service because they have paid less for tickets. In a similar vein, Bhadra (2009) has put forth the fact that expectations regarding level of service and ticket fares have a positive relationship, and FSNA passengers, who pay more for their tickets, have higher expectations. In accordance with the positive 
relationship between ticket fares and level of expectations (Bhadra, 2009; Wittman, 2014), flagship airlines passengers are expected to have higher expectations for service experience.

Expectancy disconfirmation model states that the satisfaction of customers is dependent on their expectations, actualized performance, and disconfirmation of expectations and performance (Smith and Bolton, 2002). According to Bitner (1990), when initial service performance surpasses expectation, positive disconfirmation occurs and when performance falls behind expectation, negative disconfirmation occurs. When considered from expectancy disconfirmation framework, a failure may also be defined as a negative difference between expectation and actualized performance. Concordantly, negative disconfirmation caused by a failure experience may result in further negative evaluations (Rego et al., 2009).

\section{Stability Attribution}

Attribution theory focuses on individual's causal explanations in regard to their own behavior and others' actions, particularize underlying factors that stimulate them to examine causally relevant information, examines the way of processing information to relate the causes to the occurrences and the cognitive and behavioral consequences (Monson and Snyder, 1977; Weiner, 2000).

Weiner (1980) defines stability dimension as the evaluation of causes either as temporary or permanent over time. In other words, stability can be explained as the extent to which a cause is perceived as variable or enduring over time (Hess et al., 2003). Failures with enduring causes occur more frequently, and influence consumers' expectations regarding future performance of firms (Folkes 1984; Weiner, 2000). When compared with customers who attribute cause of a failure to unstable causes, customers who perceive the cause of a failure to be stable are more confident that the same failure will reoccur (Weiner, 1986). Concordantly, Folkes (1984) indicated that these inferences regarding the stability of a failure's cause impact customers' repurchase behaviors. For instance, if a flight delay is due to a stable reason, passengers are less willing to prefer the same airlines again, whereas if it is due to an unstable reason, passengers are more willing to repurchase service from the same airlines (Folkes et al., 1987).

Customers' level of expectation acts as a baseline for formation of judgments (Oliver, 1981) and affect the way they perceive the reality (Boulding et al., 1993). Starting from this point, it can be assumed that consumers' attributes regarding cause of a negative event, such as a service failure is being formed around their expectations. Consequently, it can be stated that expectations in relation with airlines' business model may have different type of relationship with stability dimension regarding service failure.

Oliver (1981) suggested that customers' level of expectation acts as a baseline for formation of judgements. Starting from this point, it can be assumed that consumers' attributes regarding the cause of a service failure is being formed around their expectations. When an airlines company falls behind expectation of passengers, and thus expectancy disconfirmation occurs, passengers are expected to show tendency to attribute failure to causes related with that airlines. Therefore, it is expected that following a service failure, expectations will have a positive influence on stability attributions.

H1.a: In flagship airlines service failures, expectation has a positive influence on stability attributions.

H1.b: In LCC service failures, expectation has a positive influence on stability attributions.

\section{Repurchase Intentions}

The post-failure process begins when customers evaluate the consumed service, and ends with completion of both behavioral and/or non-behavioral reactions to the failure (Day, 1980). Repurchase intention refers to customers' reaction to a service experience in terms of willingness of patronizing the firm in the future (Oliver and Swan, 1989).

According to Torres and Kline (2006), building long lasting relationships with customers by retaining them is more profitable than acquiring new customers. Furthermore, willingness of customers to keep on doing business with the same firm holds both economic and non-economic advantages for companies (Mostert et al., 2009). Economic advantages include ability of forecasting future sales, reduction in marketing and acquisition costs of customers, and willingness of customers to pay premium prices, while non-economic advantages include improvement of product and service offerings (Rosenberg and Czepiel, 1983; Payne, 1993; Reichheld, 1996; Ahmad and Buttle, 2001; Kassim and Souiden, 2007). For given reasons, repurchase intention holds important place in transportation sector including air travel service providers. 
Perceived stability of a failure may influence consumers' intention to repurchase. When compared with customers who attribute cause of a failure to unstable causes, customers who perceive the cause of a failure to be stable are more confident that the same failure will reoccur (Weiner, 1986). Concordantly, Folkes (1984) indicated that these inferences regarding the stability of a failure impact customers' repurchase behaviors. For instance, if a flight delay is due to a stable reason, passengers are less willing to prefer the same airlines again, whereas if it is due to an unstable reason, passengers are more willing to repurchase service from the same airlines (Folkes et al., 1987). Hence, stability attribution is expected to have a negative influence on repurchase intentions both for LCCS and flagship airlines.

H2.a: In flagship airlines service failures, stability attribution has a negative influence on repurchase intentions.

H2.b: In LCC service failures, stability attribution has a negative influence on repurchase intentions.

\section{Word-of-Mouth}

Word of mouth (WOM) is defined as a person-to-person, informal conversation, regarding a certain product, service or brand, which does not contain any commercial bias (East et.al, 2008). WOM may either be positive and constructive, by encouraging usage of a specific product or service, or be negative and destructive complaint, by discouraging usage of a specific product or service.

According to Ziethaml et. al. (1996), WOM holds a special place for services due to their nature of being intangible which makes services riskier, harder to rely on, and difficult to standardize. It is found that, when compared with consumers of goods, consumers of services tend to have a greater confidence in personal sources of information (Murray, 1991). Additionally, negative effects of service failures spread as consumers share their dissatisfying experiences with other individuals (Kim et. al, 2010). Keaveney (1995) supported this fact by putting forward that $50 \%$ of service provider substitutions were done in this way.

Folkes (1984) and Folkes et al. (1987) analyzed complaining behavior from attributional perspective. They highlighted the fact that causal attribution dimensions; locus of control, controllability and stability of a failure influence the complaining frequency. Additionally, by analyzing the responses of airline pas- sengers awaiting delayed flights, Folkes et al. (1987) found that anger acts as a mediator between causal attribution dimensions and complaining behavior or repurchase intentions. Therefore, stability attribution is expected to have a negative influence on WOM intentions both for LCCs and flagship airlines.

H3.a: In flagship airlines service failures, stability attribution has a negative influence on WOM intentions.

H3.b: In LCC service failures, stability attribution has a negative influence on WOM intentions.

\section{Research Methodology}

According to Churchill and lacobucci (2005), conducting a pilot study before data collection plays a key role in ensuring questionnaire construction. Since the participation of at least ten individuals is suggested by Fink (1995), in this research, a pre-test was conducted by inviting 15 respondents to participate and share their insights. Academicians and doctoral, master's degree and bachelor students from different major areas of a well-known university participated to the pilot study. Valuable feedbacks regarding grammar, wording and design of the survey were provided. Accordingly, a definition and examples for "flagship airlines" were provided in order to make the term more understandable for respondents.

Firstly, a confirmatory factor analysis (CFA) has been carried out in order to test the measurement model's fit, which is built upon strong theoretical works. Thereafter, due to existence of various latent variables, structural equation modeling (SEM) is utilized, since it enables analyzing latent variables, their relationships, and holds an illustrative power of path diagrams (Nachtigall et al., 2003). By this way we provide a comparison for LCC and flagship airlines for the same model.

\section{Sampling and Data Collection}

The proposed research model is tested by surveying individuals living in Izmir. Two interviewers, who were trained for preventing any possible interviewer biases, were charged for gathering data from the field. Data was collected from four different provinces of Izmir which were selected based on their high population. Convenience sampling, which is a non-probabilistic sampling method, was employed to construct the sample handily. Since this study employs airline service failures as area of interest, the universe itself is bounded to the people who have experienced at 
least one flight within the last year, which is the reason of existence for the question regarding the number of flights experienced within last one year.

In total 600 surveys were delivered in order to obtain accurate number of completed surveys. Survey was filled by 547 respondents, from which 512 valid surveys gathered. 35 of 547 surveys were invalid due to incomplete surveys. In order to provide construct validity, respondents with age of 18 and above were taken as the target of our study. Basing on different studies in Turkey (i.e. Eroğlu, 2016; Yenipazar and Turhan, 2017), we provide the summary of respondents' demographics.

Table 1. Demographic Characteristics of the Sample

\begin{tabular}{|l|c|c|c|}
\hline & & $\mathbf{N = 5 1 2}$ & $\%$ \\
\hline \multirow{3}{*}{ Gender } & Female & 290 & 56,6 \\
& Male & 222 & 43,4 \\
\hline \multirow{4}{*}{ Education } & Primary School & 13 & 2,5 \\
& Secondary School & 51 & 10 \\
& High School & 213 & 41,6 \\
& Unsociate Degree & 58 & 11,3 \\
& Master's Degree & 24 & 4,7 \\
& PhD Degree & 11 & 2,1 \\
\hline \multirow{4}{*}{ Age } & $18-24$ & 82 & 16 \\
& $25-31$ & 139 & 27,1 \\
& $32-38$ & 149 & 29,1 \\
& $39-45$ & 87 & 17 \\
& $46-52$ & 37 & 7,2 \\
& 53 and above & 18 & 3,5 \\
\hline \multirow{5}{*}{ Income } & $0-1000$ & 74 & 14,5 \\
& $1001-2000$ & 141 & 27,5 \\
& $2001-3000$ & 163 & 31,8 \\
& $3001-5000$ & 104 & 20,3 \\
& $50001-7500$ & 19 & 3,7 \\
& 7501 and above & 11 & 2,1 \\
\hline
\end{tabular}

\section{Measures}

Expectation measures were gathered from the study of Voss et al. (1998), who developed five-item expectation scale based on service quality dimensions identified by Parasuraman et al. (1988). We used the four-item stability attribution scale of Vázquez-Casielles et al. (2007). A four-item scale for repurchase intentions was obtained from the study of Nikbin et al. (2011). Finally, three-item WOM scale was taken from the study of Maxham III (2001). Multi-item scales were employed in order to increase the quality of the measurement. Ratings were made on a 5-point Likert scale with points ranging from $1=$ "strongly disagree" to $5=$ "strongly agree".

\section{Confirmatory Factor Analysis (CFA) Results}

We employed a confirmatory factor analysis (CFA) in order to test the measurement model's fit. Overall fit of the data to the model was tested for both low cost carriers and flagship carriers. Due to poor factor loadings, we deleted one item both from repurchase intention and WOM scales. As shown in Table 2, results of CFA for both LCCs and flagship airlines in terms of Chi-square Value, Root Mean Square Error of Approximation (RMSEA), Comparative Fit Index (CFI), Tucker-Lewis Index (TLI), Goodness of Fit Index (GFI), Adjusted Goodness of Fit Index (AGFI), and Root Mean Square Residual (RMR) indicates a good model fit. Solely the Normed Fit Index (NFI) values are to a minor extend below .90 . Subsequently, CFA provides evidence of acceptable model fit and assures that the data fits to the proposed measurement model. Results are shown in Table 2.

Table 2. Goodness of Fit Statistics Resulting from CFA

\begin{tabular}{|c|c|c|c|c|}
\hline $\begin{array}{l}\text { Fit } \\
\text { Index }\end{array}$ & LCC & FLG* & Criteria & Reference \\
\hline$x 2 / d f$ & 3.462 & 2.508 & $<5$ & Bentler (1989) \\
\hline$P$ & 0.000 & .000 & $<0.05$ & Awang (2012) \\
\hline $\mathrm{CFI}$ & 0.958 & 0.975 & $>0.90$ & $\begin{array}{l}\text { Hair et al. (2010), } \\
\text { Awang (2012) }\end{array}$ \\
\hline $\mathrm{NFI}$ & 0.943 & 0.959 & $>0.90$ & Awang (2012) \\
\hline GFI & 0.937 & 0.955 & $>0.80$ & $\begin{array}{c}\text { Forza \& Filippini } \\
\text { (1998),Greenspoon \& } \\
\text { Saklofske (1997) }\end{array}$ \\
\hline AGFI & 0.902 & 0.932 & $>0.80$ & $\begin{array}{l}\text { Cole (1987), Kim \& } \\
\text { Smith (2007) }\end{array}$ \\
\hline TLI & 0.944 & 0.967 & $>0.90$ & $\begin{array}{c}\text { Forza \& Filippini } \\
\text { (1998), Awang (2012) }\end{array}$ \\
\hline RMSEA & 0.069 & 0.054 & $<0.08$ & Awang (2012) \\
\hline
\end{tabular}

Note: FLG: Flagship Airlines, LCC: Low Cost Carrier

\section{Validity and Reliability of the Study}

CFA was employed in order to assess the validity of the measures. For discriminant validity testing, Fornell-Larcker Test (Fornell and Larcker, 1981) was conducted. AVE values are taken as indicators of validity and since all the AVE values exceed 0.5 threshold level, convergent validity was confirmed (Hair et al., 2010). Besides, both maximum shared square variance (MSV) and average shared square variance (ASV) values are less than average variance extracted (AVE) values, and all of the AVE values exceed the square of 
the correlation between constructs, and thus, discriminant validity was ensured (Fornell and Larcker, 1981; Hair et al., 2010). Table 3 shows all the validity related scores of repurchase intention, expectation, stability and WOM scales.

In order to test the reliability of scales, composite reliabilities were used and as shown in Table 3, they are all above 0.7 threshold (Fornell and Larcker, 1981; Hair et al., 2010).

Table 3. Validity and Reliability Table for LCC and FLG

\begin{tabular}{lcccccccc}
\hline LCC & & & & & & & & \\
\hline & CR & AVE & MSV & ASV & RI & EXP & STAB & WOM \\
RI & 0,884 & 0,720 & 0,041 & 0,026 & 0,849 & & & \\
EXP & 0,928 & 0,722 & 0,041 & 0,026 & 0,202 & 0,849 & & \\
STAB & 0,800 & 0,506 & 0,036 & 0,019 & $-0,010$ & 0,191 & 0,711 & \\
WOM & 0,824 & 0,708 & 0,036 & 0,019 & 0,189 & 0,028 & $-0,143$ & 0,841 \\
\hline FLAGSHIP & & & & & & & \\
\hline RI & 0,890 & 0,733 & 0,141 & 0,054 & 0,856 & & & \\
EXP & 0,906 & 0,662 & 0,007 & 0,002 & 0,086 & 0,814 & & \\
STAB & 0,850 & 0,591 & 0,034 & 0,016 & $-0,121$ & $-0,004$ & 0,769 & \\
WOM & 0,810 & 0,687 & 0,141 & 0,058 & 0,375 & $-0,007$ & $-0,185$ & 0,829 \\
\hline
\end{tabular}

Notes: CR: Composite Reliability, AVE: Average Variance Extracted, MSV: Maximum Shared Squared Variance, ASV: Average Shared Square Variance, EXP: Expectation, STAB: Stability Attribution, RI: Repurchase Intention

\section{Findings}

\section{Results of SEM}

As shown in Table 4, both for LCCs and flagship airlines, Goodness-of-Fit Index (GFI), Adjusted Goodness-of-Fit (AGFI), Chi-square value ( $x 2 / \mathrm{df}$ ) and Comparative Fit Index (CFI) are consistent with the required threshold levels. Additionally, both for LCCs and flagship airlines Root Mean Square Error of Approximation
(RMSEA) values indicate a good fit by being close to 0.05 threshold level (MacCallum et al., 1996).

Table 4. Goodness-of-Fit Statistics for LCC and Flagship Airlines

\begin{tabular}{lcc}
\hline Fit Index & LCC & FLG \\
\hline $\mathrm{X} 2 / \mathrm{df}$ & 3,470 & 2,860 \\
$\mathrm{P}$ & .000 & .000 \\
$\mathrm{CFI}$ &, 950 &, 963 \\
$\mathrm{NFI}$ &, 932 &, 944 \\
$\mathrm{GFI}$ &, 930 &, 943 \\
$\mathrm{AGFI}$ &, 896 &, 917 \\
RMSEA &, 070 &., 060 \\
\hline
\end{tabular}

The findings indicate that expectations have a positive influence on stability attributions following low cost airlines service failures ( $\beta$ : 0.183; e: $0.036 ; p=$ $0.00)$. However, expectations do not have an influence on stability attributions following FLG service failures ( $\beta$ : -0.008 ; e: $0.06 ; p=0.87$ ). Therefore, H1.a. is not supported, whereas H1.b. is supported.

In a similar vein, stability attribution has no impact on repurchase intentions following LCC failures ( $\beta$ : 0.003; e: 0.06; $p=0.957$ ). However, following flagship airlines service failures, stability negatively affects repurchase intention $(\beta:-0,132$; e: $0.052 ; p=0.006)$. Hence, H2.a is supported, whereas H2.b is not supported.

Additionally, stability attribution has negative impacts on word of mouth in failures of both flagship ( $\beta$ : $-0.117 ;$ e: $0.051 ; p=0.000)$ and low cost airlines $(\beta$ : -0.103; e: 0.059; $p=0.007$ ). Concordantly, both H3.a and $\mathrm{H} 3 . \mathrm{b}$ are supported. Results of SEM are given in Table 5 , and are schematized for flagship airlines and LCCs respectively in Figure 2 and Figure 3.

Table 5. Results of SEM

\begin{tabular}{|c|c|c|c|c|c|}
\hline & $\begin{array}{c}\text { Unstandardized } \\
\text { Regression Weights }\end{array}$ & $\begin{array}{c}\text { Standardized } \\
\text { Regression Weights }\end{array}$ & S.E. & C.R. & $\mathbf{P}$ \\
\hline \multicolumn{6}{|l|}{ Flagship Airlines } \\
\hline $\mathrm{STAB} \leftarrow \mathrm{EXP}$ & -0.01 & -0.008 & 0.06 & -0.163 & 0.87 \\
\hline $\mathrm{RI} \leftarrow \mathrm{STAB}$ & -0.143 & -0.132 & 0.052 & -2.756 & 0.006 \\
\hline $\mathrm{WOM} \leftarrow \mathrm{STAB}$ & -0.217 & -0.117 & 0.051 & -4.237 & $* * *$ \\
\hline \multicolumn{6}{|l|}{ LCCs } \\
\hline$S T A B \leftarrow E X P$ & 0.135 & 0.183 & 0.036 & 3.774 & $* * *$ \\
\hline $\mathrm{RI} \leftarrow \mathrm{STAB}$ & 0.003 & 0.003 & 0.06 & 0.053 & 0.957 \\
\hline $\mathrm{WOM} \leftarrow \mathrm{STAB}$ & -0.161 & -0.103 & 0.059 & -2.708 & 0.007 \\
\hline
\end{tabular}




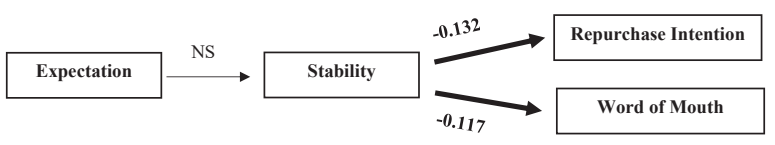

Figure 2. Final Model with Hypotheses Test Results for Flagship Airlines

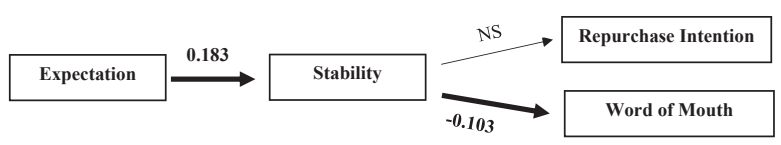

Figure 3. Final Model with Hypotheses Test Results for LCCS

\section{Discussion of the Results}

This research focuses on attributions and reactions of passengers following failure incidences, and contributes to the service failure and aviation research by highlighting the relations among expectations, stability attributions and behavioral intentions. Furthermore, the current study broadens the extant body of knowledge in the field through examining the aforementioned relationships separately for two distinct passenger airlines business models, namely as flagship airlines and LCCs.

Results of this study indicate that following low cost airlines service failure, expectations and stability attribution have a positive relationship. Such relationship following a service failure may be explained by expectation disconfirmation paradigm, which states that when initial service performance exceeds pretrial expectation, positive disconfirmation occurs and in cases where performance falls behind pretrial expectation, negative disconfirmation occurs (Bitner, 1990). Concordantly, negative disconfirmation caused by a failure experience may lead further negative evaluations (Rego et al., 2009). In line with this line of thought, it may be noted that, following LCC service failures, passengers experience a negative expectation disconfirmation that, in turn, leads attributing cause of failure to be stable over time. On the other hand, surprisingly, relationship between expectation and stability is found to be insignificant for flagship airlines.

Related literature states that customers who perceive the cause of a failure to be stable are more confident that the same failure will reoccur (Weiner, 1986), and concordantly, stability impacts customers' repurchase behaviors (Folkes, 1984). For flagship airlines, findings of the study are congruent with the previous literature.
When the customers perceive high stability in failures, they lower repurchase intentions for the flagship airlines. On the other hand, for LCC service encounter, a relationship between stability and repurchase intentions was not observed. The reason lying behind the non-existence of a statistically significant relationship between stability attribution and repurchase intentions following LCC service failures may be the nature of air transport industry. Passengers may be patronizing airlines in accordance with convenience of flights, availability of destinations, price deals and/or connected flight availability and options. Based on the literature (e.g. Vlachos and Lin, 2014; Calisir et al., 2016; Rajaguru, 2016) the underlying reason may be linked to the fact that passengers make decisions and airlines choice case-by-case for each flight and take buying action in accordance with facts regarding flight options and prices without considering past failure experiences.

Related literature indicates that when customers attribute cause of a failure to be relevant to various diverse situations, they make negative evaluations about the provider (e.g. Hess, 1999; Hess et al., 2007). Moreover, as mentioned previously, Folkes (1984) and Folkes et al. (1987) highlighted the fact that causal attribution dimensions of locus of control, controllability and stability effect the complaining behavior. In congruence with extant body of knowledge, findings of this study point out a negative relationship between stability attribution and WOM intention both for flagship airlines and LCCs. To put it another way, when passengers attribute the cause of a service failure to be stable, or permanent, over time, their intention to engage in positive WOM intention decreases. Since failures with enduring causes occur more frequently, and thus concordantly influence consumers' expectations regarding future performance of firms (Folkes 1984; Weiner, 2000), negative relationship between stability attribution and WOM intention is legitimate.

This study contributes to the practitioners in aviation industry by providing managerial implications separately for LCCs and flagship carriers. Findings reveal that airlines' business model creates noteworthy differences among dynamics by which passengers evaluate service failures. The practitioners in low cost airlines should be aware of the link among expectations and stability attributions. Besides, in flagship airlines, if the customers perceive the failures as enduring and stable, their intention to repurchase and engage in positive WOM decrease. Since positive WOM plays a significant role in marketing, practitio- 
ners in LCC and flagship airlines should be the ones that convince the customers about the instability of failures experienced. Information provision with explanation and communication during and after failures gain importance in this persuasion process.

\section{Limitations and Recommendation for Further Research}

This study has its own limitations, which may also limit findings of the study. First, the severity effect of the failure has not been investigated in this study. For a passenger going to an important business meeting, the effect of a 30-minutes-delay may conclude in different attributional responses. Thus, failure severity in airlines context is worthy for further investigation.

Secondly, service failures may occur at different levels; at employee level or at organizational level. For different cases involving different level of service failures, behavioral intentions and attributions following a service failure may vary. For example, a passenger may be more propitious in terms of repurchase intentions in case of having a negative experience with an impolite stewardess, when compared with the case of cancellation of a flight without giving a notice. In accordance, failures may be categorized as employee-level and organization-level for further investigation of the model.

Furthermore, this study examines the data obtained solely from Turkish passengers. The study may be broadened by obtaining data from international passengers from different cultures. Consumers from different cultures are found to have dissimilar levels of service expectations, and behavioral and attributional tendencies (Patterson and Smith, 2001; Mattila and Paterson, 2004; Carpenter, 2000). Accordingly, in further researches another set of data may be obtained from citizens of a western country and a comparison may be made between individuals belonging to eastern and western culture. The comparison may supply significant managerial implications in terms of behavioral and attributional patterns of customers. 


\section{References}

Ahmad, R.; Buttle, F., 2001. Customer Retention: A Potentially Potent Marketing Management Strategy. Journal of Strategic Marketing, 9(1): 29-45.

Awang, Z., 2012. Structural equation modeling using AMOS graphic. Penerbit Universiti Teknologi MARA.

Bentler, P.M., 1989. EQS Structural Equations Program Manual, BMDP Statistical Software, Los Angeles.

Bhadra, D. (2009). You (expect to) get what you pay for: A system approach to delay, fare, and complaints. Transportation Research Part A: Policy and Practice, 43(9), 829-843.

Bitner, M. J. (1990). Evaluating service encounters: the effects of physical surroundings and employee responses. the Journal of Marketing, 69-82.

Boulding, W., Kalra, A., Staelin, R., \& Zeithaml, V. A., 1993. A dynamic process model of service quality: from expectations to behavioral intentions. Journal of marketing research, 30(1), 7 .

Calisir, N., Basak, E., \& Calisir, F., 2016. Key drivers of passenger loyalty: A case of Frankfurt-Istanbul flights. Journal of Air Transport Management, 53, 211-217.

Carpenter, S., 2000. Effects of cultural tightness and collectivism on self-concept and causal attributions. Cross-Cultural Research, 34(1), 38-56.

Churchill, G. A., and lacobucci, D., 2005. Marketing Research: Methodological Foundations (9th ed.). Mason, Ohio:Thomson South-Western.

Cole, D. A., 1987. Utility of confirmatory factor analysis in test validation research. Journal of consulting and clinical psychology, 55(4), 584.

Davis, M. M.; Heineke, J., 1998. How disconfirmation, perception and actual waiting times impact customer satisfaction. International Journal of Service Industry Management, 9(1): 64 - 73.

Day, R., 1980. "Research perspectives on consumer complaining behavior", in Theoretical Developments in Marketing, Lamb, C.W. and Dunne, P.M. (Eds), American Marketing Association, Chicago, IL, pp. 211-5.

Doganis, R., 2001. The Airline Business in the 21st Century. Routledge, London.

East, R. and et al. (2008). Measuring the Impact of Positive and Negative Word of Mouth on Brand Purchase Probability. International Journal of Research in Marketing, 25(3):215-224.
Eroğlu, F. (2016). Kompulsif Satin Alma: Kişisel Faktörler, Postmodern Tüketim Şekilleri Ve Reklama Karşi Tutumun Rolüne Yönelik Bir Araştirma. Balikesir University Journal of Social Sciences Institute, 19(35).

Fink, A., 1995. The survey handbook (Vol. 1). Thousands Oaks, CA: Sage.

Folkes, V. S. (1984). Consumer reactions to product failure: An attributional approach. Journal of consumer research, 398-409.

Folkes, V. S. (1984). Consumer reactions to product failure: An attributional approach. Journal of consumer research, 10(4), 398-409.

Folkes, V. S., Koletsky, S., and Graham, J. L., 1987. A field study of causal inferences and consumer reaction: the view from the airport. Journal of consumer research, 534-539.

Fornell, C., and Larcker, D. F., 1981. Evaluating structural equation models with unobservable variables and measurement error. Journal of marketing research, 39-50.

Forza, C., \& Filippini, R., 1998. TQM impact on quality conformance and customer satisfaction: a causal model. International journal of production economics, 55(1), 1-20.

Francis, G.; Humphreys, I.; Ison, S., 2004. Airports' Perspectives on the Growth of Low-Cost Airlines and the Remodeling of the Airport-Airline Relationship. Tourism Management, 25(4): 507-514.

Greenspoon, P. J., \& Saklofske, D. H., 1997. Validity and reliability of the multidimensional students' life satisfaction scale with Canadian children. Journal of Psychoeducational Assessment, 15(2), 138-155.

Grönroos, C., 1984. A Service Quality Model and Its Market Applications. European Journal of Marketing, 18(4): 36-44.

Hair, J. F., Black, W. C., Babin, B. J., Anderson, R. E., \& Tatham, R. L., 2010. Multivariate data analysis. Pearson.

Harris, J.; Uncles, M., 2007. Modeling the Repatronage Behavior of Business Airline Travellers. Journal of Service Research, 9(4): 297-311.

Hess, R. L., Ganesan, S., and Klein, N. M., 2003. Service failure and recovery: the impact of relationship factors on customer satisfaction. Journal of the Academy of Marketing Science, 31(2), 127-145.

Hess, R. L., Ganesan, S., and Klein, N. M., 2007. Interactional service failures in a pseudorelationship: 
The role of organizational attributions. Journal of Retailing, 83(1), 79-95.

Hunter, L., 2006. Low Cost Airlines: Business Model and Employment Relations. European Management Journal, 24(5): 315-321.

Kassim, N.M.; Souiden, N., 2007. Customer retention measurement in the UAE banking sector. Journal of Financial Services Marketing, 11(3): 217-228.

Keaveney, S. M. (1995). Customer switching behavior in service industries: An exploratory study. The Journal of Marketing, 71-82.

Kim, W., and Ok, C. (2010). Customer orientation of service employees and rapport: Influences on service-outcome variables in full-service restaurants. Journal of Hospitality and Tourism Research, 34(1), 34-55.

Kim, Y. K., and Smith, A. K., 2007. Providing a critical service today for tomorrow's consumers: A relational model of customer evaluations and responses in the child care industry. Journal of Retailing and Consumer Services, 14(3), 232-245.

Mason, K.J., 2000. The Propensity of Business Travelers to Use Low Cost Airlines. Journal of Transport Geography, 8(2): 107-119.

Mattila, A. S., and Patterson, P. G., 2004. The impact of culture on consumers' perceptions of service recovery efforts. Journal of Retailing, 80(3), 196-206.

Maxham III, J. G. (2001). Service recovery's influence on consumer satisfaction, positive word-of-mouth, and purchase intentions. Journal of business research, 54(1), 11-24.

McDougall, G.; Levesque, T., 1998. The Effectiveness of Recovery Strategies After Service Failure: An Experiment in the Hospitality Industry. Journal of Hospitality and Leisure Marketing, 5 (2/3): 27-39.

Monson, T.; Snyder, M., 1977. Actors, observers and the attribution process: Toward a reconceptualisation. Journal of Experimental Social Psychology, 43, 8911.

Mostert, P.G.; De Meyer, C.F.; Van Rensburg, 2009. The Influence of Service Failure and Service Recovery on Airline Passengers' Relationships with Domestic Airlines: An Exploratory Study. Southern African Business Review, 13(2): 118-140.

Murray, K. B. (1991). A test of services marketing theory: consumer information acquisition activities. The journal of marketing, 10-25.

Nachtigall, C., Kroehne, U., Funke, F., and Steyer, R., 2003. Pros and Cons of Structural Equation
Modeling. Methods of Psychological Research Online, 8(2), 1-22.

Nikbin, D., Ismail, I., Marimuthu, M., \& Younis Abu-Jarad, I., 2011. The impact of firm reputation on customers' responses to service failure: the role of failure attributions. Business Strategy Series, 12(1), 19-29.

O'Connell, J. F.; Williams, G., 2005. Passengers' Perceptions of Low Cost Airlines and Full Service Network Carriers: A Case Study Involving Ryanair, Aer Lingus, Air Asia and Malaysia Airlines. Journal of Air Transport Management, 11(4): 259-272.

Oliver, R .L., Swan, J. E., 1989. Consumer Perceptions of Interpersonal Equity and Satisfaction in Transactions: A Field Survey Approach. Journal of Marketing, 53: 21-35.

Oliver, R. L., 1981. Effect of Satisfaction and Its Antecedents on Consumer Preference and Intention. Advances in Consumer Research, 8: 89-93.

Ozenen C.G., 2003. Havaalanı Yatıımlarında Özelleştirme Dünyadaki Uygulamalar ve Türkiye İçin Öneriler. Ankara: Devlet Planlama Teşkilatı.

Parasuraman, A., Zeithaml, Valerie A. and Berry, Leonard L., 1988. "SERVQUAL: A Multiple Item Scale for Measuring Consumer Perceptions of Service Quality," Journal of Retailing, 64 (Spring), 12-40.

Patterson, P. G., and Smith, T., 2001. Relationship benefits in service industries: a replication in a Southeast Asian context. Journal of Services Marketing,15(6), 425-443.

Payne, J., 1993. The Adaptive Decision Maker. Cambridge, UK: Cambridge Press.

Rajaguru, R., 2016. Role of value for money and service quality on behavioural intention: A study of full service and low cost airlines. Journal of Air Transport Management, 53, 114-122.

Rego, L.L., Billett, M.T., \& Morgan, N.A. (2009). Consumer-based brand equity and firm risk. Journal of Marketing, 73, 47-60.

Reichheld, F., 1996. The Loyalty Effect. Boston: Harvard Business School Press.

Rosenberg, L. J., Czepiel, J. A., \& Cohen, L. C. (1977). Consumer Affairs Audits: Evaluation and Analysis. California Management Review, 19(3), 12-20.

Smith, A. K., and Bolton, R. N., 1998. An experimental investigation of customer reactions to service failure and recovery encounters paradox or peril? Journal of service research, 1(1), 65-81.

Sull, D., 1999. EasyJet's $\$ 500$ million gamble. European Management Journal, 17(1), 20-32. 
Taumoepeau, S., Towner, N., \& Losekoot, E., 2017. LowCost Carriers in Oceania, Pacific: Challenges and opportunities. Journal of Air Transport Management, $65,40-42$.

Teas, R. K., 1981. An Empirical Test of Models of Salespersons, Job Expectancy and Instrumentality Perceptions. Journal of Marketing Research, 18(2): 209-226.

Torres, E.N. and Kline, S., 2006. From Satisfaction to Delight: A Model for the Hotel Industry. International Journal of Contemporary Hospitality Management., 18(4):290 - 301.

Vázquez-Casielles, R. et al., 2007. Quality of Past Performance: Impact on Customers' Responses to Service Failure. Marketing Letters, 18(4): 249-264.

Vidović, A.; Štimac, I.; Vince, D., 2013. Development of Business Models of Low-cost Airlines. International Journal for Traffic and Transport Engineering, 3(1): 69-81.

Vlachos, I., \& Lin, Z. (2014). Drivers of airline loyalty: Evidence from the business travelers in China. Transportation Research Part E: Logistics and Transportation Review, 71, 1-17.

Voss, G. B., Parasuraman, A., \& Grewal, D., 1998. The roles of price, performance, and expectations in determining satisfaction in service exchanges. The Journal of Marketing, 46-61.

Weiner, B., 1980. A cognitive (attribution)-emotion-action model of motivated behavior: An analysis of judgments of help-giving. Journal of Personality and Social psychology, 39(2), 186.

Weiner, B., 1986. Attribution, emotion, and action. Handbook of motivation and cognition: Foundations of social behavior, 1, 281-312.

Weiner, B., 2000. Attributional thoughts about consumer behavior. Journal of Consumer research, 27(3), 382-387.

Williams, G., 2001. Will Europe's Charter Carriers Be Replaced by "No-Frills" Scheduled Airlines? Journal of Air Transport Management, 7(5): 277-286.

Wittman, M. D., 2014. Are low-cost carrier passengers less likely to complain about service quality? Journal of Air Transport Management, 35, 64-71.

Yenipazar, E., \& Turan, A. H. (2017). Son Kullanici Bilgi Teknolojileri Tatmini Sakarya Üniversitesi Sabis Örneği. Suleyman Demirel University Journal of Faculty of Economics \& Administrative Sciences, 22(2).

Zeithaml, V. A., Berry, L. L., and Parasuraman, A. (1996). The behavioral consequences of service quality. The Journal of Marketing, 31-46. 